\title{
A study on evaluation of foetal thyroid volume in aborted foetus by ellipsoid method in relation to gestational age
}

\author{
Usha Kothandaraman ${ }^{1}$, S. Lokanadham, ${ }^{2, *}$ \\ ${ }^{1}$ Professor, ${ }^{2}$ Assistant Professor, Dept. of Anatomy, ESIC Medical College, Chennai, Tamil Nadu, ${ }^{2}$ Santhiram Medical College, \\ Nandyal, Andhra Pradesh, India
}

*Corresponding Author: S. Lokanadham

Email: loka.anatomy@yahoo.com

Received: $28^{\text {th }}$ October, 2016

Accepted: $4^{\text {th }}$ August, 2018

\begin{abstract}
Introduction: Thyroid volume measurement is a better reflection of thyroid gland growth than any other linear dimension of the organ. Foetal thyroid volume is significantly correlated with gestational age and foetal weight.

Aim: To evaluate the foetal thyroid volume in relation to the gestational weeks.

Materials and Methods: A total of 22 (Male - 9; Female - 13) aborted foetuses were collected from the department of Anatomy, ESIC Medical College \& PGIMSR, Chennai.

Results: We have observed there was significant increase in thyroid volume with the correction factor (CF-0.479) by ellipsoid method in relation to gestational weeks. Thyroid volume with correction factor was noted to be more in males as compared to females in all gestational age groups. There was a gradual increase in thyroid weight in relation to thyroid volume in all groups of gestational ages in our study.

Conclusion: The present study evaluated the foetal thyroid volume in relation to the gestational age in aborted foetuses and also suggested the volume related changes of the thyroid gland in foetal life and its abnormalities.
\end{abstract}

Keywords: Evaluation, Gestation, Thyroid, Volume.

\section{Introduction}

Thyroid volume is increased in thyroid dyshormonogenesis while it is decreased in thyroid hyperplasia. ${ }^{1}$ Volumetric evaluation of the thyroid gland is based on the use of an ellipsoid model to measure in $\mathrm{cm}^{3}$. With the ellipsoid model, the height, width, and thickness of each lobe are measured and multiplied. The obtained result is then multiplied by a correction factor, which is $\pi / 6$, or $0.524 .^{2-4} \mathrm{~A}$ strong correlation was found between the volume of the thyroid gland calculated by ultrasonography and the volume assessed after dissection of the gland and immersion in water. ${ }^{5}$ Volume measurement of autopsy thyroid glands subsequently immersed in water by using a modified correction factor of 0.479 resulted in a more accurate assessment of thyroid volume compared with the previously accepted correction factor of $\pi / 6$, or $0.524 .{ }^{6}$ The size of the foetal thyroid gland may be indicative of foetal or postnatal complications. The aim of the present study was to evaluate the foetal thyroid volume by using ellipsoid method in aborted foetuses in relation to gestational age.

\section{Materials and Methods}

A total of 22 (Male - 9; Female - 13) formalin preserved dead embryos and foetuses with relevant obstetric records available in Department of Anatomy, ESIC Medical College \& PGIMSR, Chennai were utilized for this study. The foetuses were of 16-40 weeks of gestational age. The foetuses were preserved by injecting $10 \%$ formalin solution into the pleural, peritoneal and the cranial cavities. Isolation of thyroid gland from its neighbouring structures in the neck was done by dissection method. The physical measurements of the thyroid gland i.e. length, width, thickness and weight were recorded (Fig. 1a). The specimens were categorized into 16-24 weeks, 26-34 weeks and $\geq 36$ weeks of gestational ages. We have evaluated the thyroid volume by using ellipsoid method equation $(\pi / 6 \mathrm{x}$ Length $\mathrm{x}$ Width $\mathrm{x}$ Thickness of the thyroid gland) in relation to the gestational ages (Fig. 1b). The present work was approved from the ethical committee of ESIC Medical College, Chennai. The data were processed and statistical analyses were done by unpaired students ' $\mathrm{t}$ ' test and one-way ANOVA test. All the statistical analyses were done by using the SPSS 11.0 version.

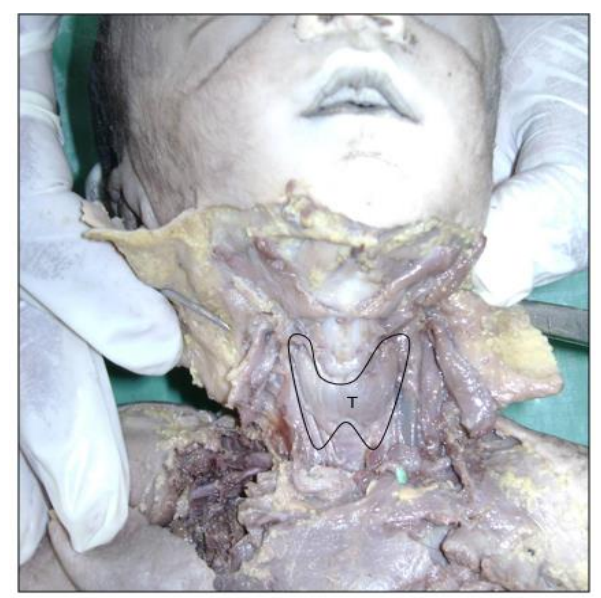

Fig. 1a: Thyroid gland in aborted foetus (insitu) by dissection method 


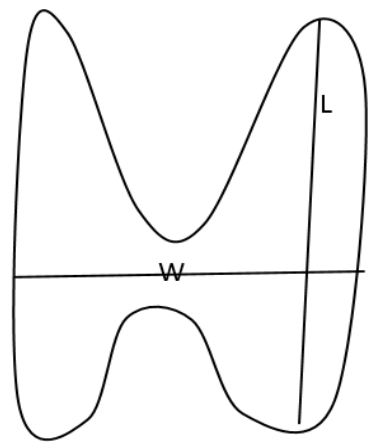

Fig. 1b: Ellipsoid method measurements of thyroid gland: Length of the gland - L; W-Width of the gland; TThickness of the gland (Antero - posterior length)

Table 1: Foetal thyroid volume and thyroid weight in 16-24 gestational weeks

\begin{tabular}{|l|c|c|c|c|c|c|c|}
\hline S. No. & $\begin{array}{c}\text { Age } \\
\text { (Weeks) }\end{array}$ & Sex & Length & Width & Thickness & $\begin{array}{c}\text { Thyroid volume } \\
\text { (CF- 0.479) }\end{array}$ & $\begin{array}{c}\text { Thyroid } \\
\text { weight (Gms) }\end{array}$ \\
\hline 1 & 16 & Female & 0.5 & 1.2 & 0.2 & 0.057 & 2.0 \\
\hline 2 & $16-22$ & Male & $0.7 / 1.0$ & 1.6 & 0.2 & 0.130 & 2.0 \\
\hline 3 & 18 & Female & 0.7 & 1.1 & 0.1 & 0.036 & 2.1 \\
\hline 4 & $18-20$ & Male & 0.8 & 1.2 & 0.2 & 0.045 & 2.0 \\
\hline 5 & 20 & Female & 0.8 & 1.8 & 0.2 & 0.137 & 2.0 \\
\hline 6 & $22-23$ & Male & $1.2 / 0.9$ & 1.8 & 0.3 & 0.271 & 4.0 \\
\hline 7 & $22-24$ & Male & $1.0 / 1.3$ & 2.2 & 0.3 & 0.363 & 3.0 \\
\hline \multicolumn{7}{|c|}{ Mean } \\
\hline \multicolumn{7}{|c|}{ P-value } \\
\hline
\end{tabular}

Table 2: Foetal thyroid volume and thyroid weight in 26-34 gestational weeks

\begin{tabular}{|c|c|c|c|c|c|c|c|}
\hline S. No & $\begin{array}{c}\text { Age } \\
\text { (Weeks) }\end{array}$ & Sex & Length & Width & Thickness & $\begin{array}{c}\text { Thyroid volume } \\
\text { (CF- 0.479) }\end{array}$ & $\begin{array}{c}\text { Thyroid } \\
\text { weight }\end{array}$ \\
\hline 1 & 26 & Male & 1.0 & 1.6 & 0.2 & 0.153 & 2.0 \\
\hline 2 & 28 & Female & $1.3 / 0.8$ & 1.9 & 0.3 & 0.286 & 3.5 \\
\hline 3 & 28 & Female & $1.1 / 0.8$ & 2.1 & 0.4 & 0.381 & 3.0 \\
\hline 4 & 32 & Female & $1.1 / 1.3$ & 2.2 & 0.3 & 0.363 & 3.0 \\
\hline 5 & $34-36$ & Male & 1.2 & 2.2 & 0.3 & 0.379 & 3.5 \\
\hline \multicolumn{6}{|c|}{ Mean } & 0.3100 & 3.0000 \\
\hline \multirow{2}{*}{\multicolumn{6}{|c|}{ Standard Deviation }} & 0.0970 & 0.6120 \\
\hline & & & & & P-value & $\mathrm{P}<0.05$ & $\mathrm{P}<0.05$ \\
\hline
\end{tabular}

Table 3: Foetal thyroid volume and thyroid weight in $\geq \mathbf{3 6}$ gestational weeks

\begin{tabular}{|c|c|c|c|c|c|c|c|}
\hline S. No & $\begin{array}{c}\text { Age } \\
\text { (Weeks) }\end{array}$ & Sex & Length & Width & Thickness & $\begin{array}{c}\text { Thyroid volume } \\
\text { (CF- 0.479) }\end{array}$ & $\begin{array}{c}\text { Thyroid } \\
\text { weight }\end{array}$ \\
\hline 1 & 36 & Male & 2.0 & 3.1 & 0.6 & 1.781 & 4.0 \\
\hline 2 & 36 & Female & 1.5 & 2.9 & 0.5 & 1.041 & 4.0 \\
\hline 3 & 36 & Male & 1.9 & 1.8 & 0.6 & 0.982 & 4.0 \\
\hline 4 & 36 & Male & 1.9 & 3.1 & 0.6 & 1.692 & 3.8 \\
\hline 5 & 36 & Female & 1.2 & 2.3 & 0.5 & 0.661 & 3.8 \\
\hline 6 & 36 & Female & 1.2 & 2.2 & 0.6 & 0.758 & 3.5 \\
\hline 7 & 36 & Female & $1.2 / 1.6$ & 2.6 & 0.4 & 0.697 & 3.8 \\
\hline 8 & 36 & Female & $2.2 / 1.2$ & $0.7 / 0.8$ & $0.5 / 0.4$ & 0.275 & 4.0 \\
\hline 9 & 38 & Female & $1.3 / 1.6$ & 2.9 & 0.5 & 1.006 & 4.0 \\
\hline 10 & $38-40$ & Female & 1.7 & 2.9 & 0.4 & 0.994 & 4.1 \\
\hline \multicolumn{6}{|c|}{ Mean } & 0.9900 & 3.9000 \\
\hline \multicolumn{6}{|c|}{ Standard Deviation } & 0.4570 & 0.1760 \\
\hline \multicolumn{6}{|c|}{$\mathrm{P}$-value } & $\mathrm{P}<0.05$ & $\mathrm{P}<0.05$ \\
\hline
\end{tabular}

\section{Results}

The foetal thyroid volume in 16-24 gestational weeks was $0.1500 \pm 0.1250 \mathrm{~cm}^{3}$ (CF-0.479) and foetal thyroid weight was $2.4400 \pm 0.7790$. In $26-34$ weeks of gestational age group the foetal thyroid volume was $0.3100 \pm 0.0970 \mathrm{~cm}^{3}(\mathrm{CF}-0.479)$ and foetal thyroid weight 
was $3.0000 \pm 0.6120$. The foetal thyroid volume in $\geq 36$ weeks was $0.9900 \pm 0.4570 \mathrm{~cm}^{3}(\mathrm{CF}-0.479)$ and foetal thyroid weight was $3.9000 \pm 0.1760$. We have observed there was significant increase in thyroid volume with the correction factor (Calculating method) in relation to gestational weeks. Thyroid volume calculated with correction factor was noted to be more in males when compared to females in all gestational groups. There was a gradual increase in thyroid weight in relation to thyroid volume in all groups of gestational ages in our study. The evaluation of thyroid volume by ellipsoid method is significant $(\mathrm{P}<0.05)$ in the present study. [Table 1-3].

\section{Discussion}

The foetal thyroid volume is significantly correlated with foetal weight and gestational age if considered independently and simultaneously. Thyroid volume was increased with age during childhood and adolescence, remained stable in young adults and declined in older subjects. The change in volume was said to be due to consequence of the changes in size of the acini of the gland. ${ }^{7}$ We have observed that there was significant increase in thyroid volume (Calculating method) in relation to gestational weeks which were in agreement with previous literatures. ${ }^{8,9}$ Hegedus et al. measured the volume of the thyroid gland in 271 subjects aged 13-92 years by ultrasonic scanning technique and observed its relationship to body weight, age and sex. ${ }^{9}$ Thyroid volume with the correction factor showed more significant values in males when compared to females in all gestational groups in our study which is one of the indicating factor of role of sex in relation to changes in thyroid volume. Fetal thyroid volume was found to increase exponentially with advancing gestational age and the growth trend was in accordance with the changes in foetal thyroxine level during gestation. ${ }^{8,10}$ The maturational phase of the foetal thyroid begins at 12-18 weeks. After 20 weeks of gestation, the foetal thyroid gland undergoes progressive functional development. ${ }^{8,11-13}$ The volume of the thyroid gland rises in a linear fashion, because of increasing size and amount of follicles and with senescence. ${ }^{14}$ The results of the present study are in agreement with the previous literatures. Evaluation of thyroid volume by ultrasonography method was already established, the current study was undertaken to evaluate the thyroid volume in aborted foetus by using ellipsoid method which will provide basic knowledge to the clinicians irrespective of some limitations.

\section{Conclusion}

The present study on foetal thyroid volume in relation to the gestational age in aborted foetuses by using ellipsoid method gives basic knowledge to clinicians about the thyroid gland growth reflection and its anomalies. ${ }^{15}$

\section{Acknowledgements}

Authors are thankful to Dr. V. Subhadradevi for her valuable guidance and advice during this work. Authors acknowledge the immense help received from Prof. R. Sekhar during the period of work.

\section{References}

1. Köksal N, Aktürk B, Saglam H, Yazici Z, Cetinkaya M. Reference values for neonatal thyroid volumes in a moderately iodine-deficient area. $J$ Endocrinol Invest. 2008;31(7):642-6.

2. Brown MC, Spencer R. Thyroid gland estimated by use of ultrasound in addition to scintigraphy. Acta Radiol Oncol Radiat Phys Biol. 1978;17:337-341.

3. Chanoine JP, Toppet V, Lagasse R, Spehl M, Delange F. Determination of thyroid volume by ultrasound from the neonatal period to late adolescence. Eur J Pediatr. 1991;150:395-9.

4. Szebeni A, Beleznay E. New simple method for thyroid volume determination by ultrasonography. J Clin Ultrasound. 1992;20:329-37.

5. Shabana W, Peeters E, De Maeseneer M. Measuring thyroid gland volume: should we change the correction factor. Am J Roentgenol. 2006;186(1):234-6.

6. Brunn J, Block U, Ruf G, Bos I, Kunze WP, Scriba PC. Volumetric analysis of thyroid lobes by realtime ultrasound (author's translation) [in German]. Dtsch Med Wochenschr. 1981;106:1338-1340.

7. Brown RA, Al-Moussa M, Beck JS. Histometry of normal thyroid in man. J Clin Pathol. 1986; 39(5):47582.

8. S.S.Y.Ho and C. Metreweli. Normal fetal thyroid volume. Ultrasound Obstet Gynecol. 1998;11:118-122.

9. Hegedus L, Perrild H, Poulsen LR, Andersen JR, Holm $\mathrm{B}$, Schnohr P, et al. The determination of thyroid volume by ultrasound and its relationship to body weight, age, and sex in normal subjects. J Clin Endocrinol Metab. 1983;56(2):260-3.

10. Thorpe-Beeston JG, Nicolaides KH, Snijders RJM, Felton CV, Butler J, McGregor AM. Maturation of the secretion of thyroid hormone and thyroid stimulating hormone in the fetus. N Engl J Med. 1991;324:532-6

11. Becks GP, Burrow GN. Thyroid disease and pregnancy. Med Clin North Am. 1991;75:121-50.

12. Keeling JW. Fetal and Neonatal Pathology, 2nd edn. London: Springer-Verlag, 1993:512-15.

13. Shulman DI, Root AW. Thyroid dysfunction. In Sweet AY, Brown EG, eds. Fetal and Neonatal Effects of Maternal Disease. St. Louis: Mosby Year Book, 1991:328-36.

14. Roberts PF. Variation in the morphometry of the normal human thyroid in growth and ageing. J Path. 1974; 112(3): 161-8.

15. Ueda D. Normal volume of the thyroid gland in children. J Clin Ultrasound. 1990;18:455-62.

How to cite this article: Kothandaraman U, Lokanadham S. A study on evaluation of foetal thyroid volume in aborted foetus by ellipsoid method in relation to gestational age. Indian $\mathbf{J}$ Clin Anat Physiol. 2018;5(4):461-463. 